\title{
Pengaruh pemberian kecambah kacang hijau (Phaseolus radiatus (L.)) terhadap kadar malondealdehid (MDA) plasma dan jaringan hati tikus Sprague Dawley yang diberi pakan lemak tinggi
}

The effect of mung bean sprouts (Phaseolus radiates $(L)$ ) to level of plasma malondealdehyde (MDA) and liver tissue of Sprague Dawley rats with high fat diet

\author{
Novidiyanto ${ }^{1}$, Arta Farmawati ${ }^{2}$, Lily Arsanti Lestari ${ }^{3}$ \\ ${ }^{1}$ Politeknik Kesehatan Kementerian Kesehatan Pangkalpinang \\ ${ }^{2}$ Departemen Biokimia, Fakultas Kedokteran Universitas Gadjah Mada \\ ${ }^{3}$ Departemen Gizi Kesehatan, Fakultas Kedokteran Universitas Gadjah Mada
}

\begin{abstract}
Background: High fat diet increases the levels of fat, especially cholesterol and triglycerides that cause hyperlipidemia. Polyunsaturated fatty acids are very easily oxidized by free radicals reactive oxygen species (ROS) called lipid peroxidation, to produce compounds that malondealdehyde (MDA), is toxic and can damage plasma membrane and liver tissue. Mung bean sprouts are known to contain antioxidants which act to inhibit lipid peroxidation process. Objective: Determine the effect of mung bean sprouts to the level of plasma MDA and liver tissue of rats with high fat diets. Method: This research is an experimental study with only post-test design with control group. Thirty five male Sprague Dawley rats were divided into 5 groups. Group K1 received fed standard; high fat diet without mung bean sprouts (K2); high fat diet and mung bean sprouts dose of $0.5 \mathrm{~mL} / \mathrm{Gbw}$ (P1); high fat diet and mung bean sprouts dose of $1 \mathrm{~mL} / \mathrm{Gbw}(\mathrm{P2})$; high fat diet and vitamin $E$ doses of $23 \mathrm{IU}(\mathrm{P3})$. All groups were treated for 28 days. Analysis of MDA plasma and liver tissue performed after treatment. Results: Group K1 has plasma MDA levels of $1.17 \pm$ $0.14 \mathrm{nmol} / \mathrm{mL}$. Mean MDA plasma level in the group K1 Group of K1 Mean MDA plasma level in the group K2 (39.7 $\pm 0.19 \mathrm{nmol} /$ $\mathrm{mL})$ was higher than the group of $K 1(1,17 \pm 0,14 \mathrm{nmol} / \mathrm{mL})$, group $P 1(2.94 \pm 0.09 \mathrm{nmol} / \mathrm{mL})$, group $P 2(1.73 \pm 0.08 \mathrm{nmol} / \mathrm{mL})$ and group P3 $(1.53 \pm 0.07 \mathrm{nmol} / \mathrm{mL})$. Group K1 has liver tissue MDA Levels of 1,64 $\pm 0,11 \mathrm{nmol} / \mathrm{g}$. Mean MDA liver tissue level in the group of K2 $(4.90 \pm 0.29 \mathrm{nmol} / \mathrm{g})$ was higher than the group of $P 1(3.68 \pm 0.45 \mathrm{nmol} / \mathrm{g})$, group P2 $(2.27 \pm 0.10 \mathrm{nmol} / \mathrm{g})$, and group P3 $(2.01 \pm 0.11 \mathrm{nmol} / \mathrm{g})$. Conclusion: Level of MDA plasma and liver tissue of rat in group P1 and P2 was lower than level of MDA plasma and liver tissue of rat in group K1, but higher than level of MDA plasma and liver tissue of rat in group P3. There was very strong correlation between level of MDA plasma and liver tissue of rat were given the mung bean sprouts and high fat diet.
\end{abstract}

KEY WORDS: high fat diet; liver tissue MDA; MDA plasma; mung bean sprouts; vitamin E

\section{ABSTRAK}

Latar belakang: Hiperlipidemia merupakan faktor risiko terjadinya penyakit kardiovaskular seperti PJK dan stroke. Hiperlipidemia menyebabkan asam lemak tak jenuh ganda mudah teroksidasi dan menghasilkan senyawa MDA yang bersifat toksik sehingga merusak membran plasma dan jaringan hati. Kecambah kacang hijau diketahui mengandung senyawa antioksidan yang dapat menghambat proses peroksidasi lipid. Tujuan: Mengetahui pengaruh pemberian kecambah kacang hijau (KKH) terhadap kadar MDA plasma dan jaringan hati tikus Sprague Dawley yang diberi pakan lemak tinggi (PLT). Metode: Penelitian eksperimental dengan desain post-test only with control group. Tikus Sprague Dawley dibagi menjadi 5 kelompok yaitu kelompok pakan standar (K1); kelompok pakan lemak tinggi (K2); kelompok PLT dan KKH 0,5 mL/g BB (P1); kelompok PLT dan KKH $1 \mathrm{~mL} / \mathrm{g}$ BB (P2); kelompok PLT dan vitamin E 23 IU (P3). Setelah 28 hari perlakuan, dilakukan analisis kadar MDA plasma dan jaringan hati tikus pada semua kelompok. Hasil: Kelompok K1 memiliki rerata kadar MDA plasma sebesar 1,17 $\pm 0,14 \mathrm{nmol} / \mathrm{mL}$. Rerata kadar MDA plasma tikus kelompok K2 $(3,97 \pm 0,19 \mathrm{nmol} / \mathrm{mL})$ lebih tinggi daripada tikus kelompok P1 $(2,94 \pm 0,09 \mathrm{nmol} / \mathrm{mL}) ; \mathrm{P} 2$ $(1,73 \pm 0,08 \mathrm{nmol} / \mathrm{mL})$; dan P3 $(1,53 \pm 0,07 \mathrm{nmol} / \mathrm{mL})$. Kelompok K1 memiliki rerata kadar MDA jaringan hati sebesar 1,64 $\pm 0,11$

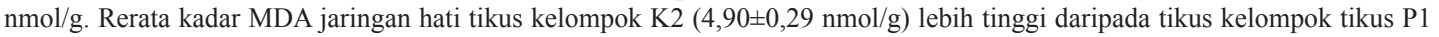
$(3,68 \pm 0,45 \mathrm{nmol} / \mathrm{g} ;$ P2 $(2,27 \pm 0,10 \mathrm{nmol} / \mathrm{g})$; dan P3 $(2,01 \pm 0,11 \mathrm{nmol} / \mathrm{g})$. Simpulan: Pemberian KKH berpengaruh terhadap

Korespondensi: Politeknik Kesehatan Kementerian Kesehatan Pangkalpinang, Komplek Perkantoran dan Pemukiman Terpadu Pemprov. Bangka Belitung, Kab. Kota Pangkalpinang, Prov. Bangka Belitung, e-mail: novidi_2011@yahoo.com 
kadar MDA plasma dan jaringan hati tikus yang diberi PLT. Kadar MDA plasma dan jaringan hati tikus kelompok P1 dan P2 lebih rendah daripada kadar MDA plasma dan jaringan hati tikus kelompok K2, tetapi lebih tinggi daripada kadar MDA plasma dan jaringan hati tikus kelompok P3. Terdapat hubungan kategori sangat kuat antara kadar MDA plasma dengan MDA jaringan hati tikus yang diberi KKH dan PLT.

KATA KUNCI: pakan lemak tinggi; MDA jaringan hati; MDA plasma; kecambah kacang hijau; vitamin E

\section{PENDAHULUAN}

Penyakit kardiovaskular menyumbang hampir setengah dari penyakit tidak menular (PTM) sebagai penyebab kematian tertinggi di dunia yaitu sebesar 17,3 juta kematian per tahun. Angka tersebut diperkirakan meningkat menjadi 23,6 juta pada tahun 2030 (1). Menurut data Riskesdas tahun 2013, salah satu dari empat jenis PTM utama menurut World Health Organization (WHO) adalah penyakit jantung koroner (PJK) dan stroke (2). Perubahan gaya hidup atau perilaku merupakan salah satu faktor penyebab hiperlipidemia (3).

Hiperlipidemia ditandai oleh peningkatan kadar kolesterol total, trigliserida, low density lipoproteincholesterol (LDL-C), dan penurunan high density lipoprotein-cholesterol (HDL-C) (4). Konsentrasi kadar LDL yang meningkat dan kandungan asam lemak tidak jenuh ganda dalam ester lipid dan kolesterol yang tinggi menyebabkan LDL mudah teroksidasi (peroksidasi lipid). Peroksidasi lipid adalah suatu reaksi oksidasi spesies oksigen reaktif(ROS) dengan asam lemak tak jenuh ganda (5). Meningkatnya radikal bebas pada hiperlipidemia berpengaruh terhadap peningkatan produk peroksidasi lipid sehingga tubuh mengalami stres oksidatif(oxidative stress) (6). Peningkatan ROS menyebabkan kerusakan sel pada protein (aktivitas enzim terganggu), asam nukleat (kerusakan DNA, mutasi sel), dan lipid (peroksidasi lipid pada membran plasma). Timbulnya penyakit degeneratif seperti liver injury dan aterosklerosis bermula dari kerusakan sel oleh ROS (5,7-9).

Stres oksidatif pada hiperlipidemia menunjukkan adanya status ketidakseimbangan antara radikal bebas, ROS, dan antioksidan pada makhuk hidup. Malondialdehid (MDA) merupakan senyawa aldehid yang terbentuk dari produk peroksidasi lipid pada asam lemak tak jenuh ganda (6). Malondealdehid bersifat toksik. Selain terdapat pada membran plasma, MDAjuga terdapat di dalam jaringan atau organ tubuh misalnya hati. Jumlah kadar produk peroksidasi lipid yang meningkat di hati dapat menyebabkan kerusakan sel hati menuju endotel pembuluh darah hingga dapat merusak organ atau jaringan lain (10).

Aktivitas antioksidan yang berasal dari makanan dan masuk di dalam tubuh, sangat tergantung dari jumlah zat yang dapat diserap dan digunakan untuk proses metabolisme. Vitamin E mempunyai efek pencegahan terhadap penyakit kardiovaskular karena vitamin E dapat melindungi asam lemak tak jenuh ganda terhadap kerusakan oksidatif dalam membran sel $(5,11)$. Salah satu bahan pangan yang sangat populer di Indonesia yaitu kecambah kacang hijau. Di Indonesia, kecambah kacang hijau dikonsumsi dalam bentuk mentah (segar) atau diolah sebagai sayuran (12). Kecambah kacang hijau diketahui mempunyai kandungan vitamin $\mathrm{E}$ dan nilai gizi yang cukup tinggi sehingga berpotensi sebagai sumber antioksidan yang berasal dari makanan (antioksidan eksogen). Kecambah kacang hijau yang diperoleh melalui proses perkecambahan kacang hijau selama 48 jam memiliki kandungan gizi yang lebih tinggi daripada tanpa proses perkecambahan. Kandungan vitamin E ( $\alpha$-tokoferol) kecambah kacang hijau sebesar $0,53 \mu \mathrm{g} / \mathrm{g}$ kecambah kacang hijau; lemak (0,54\%); protein $(35,54 \%)$; dan karbohidrat $(61,70 \%)(13,14)$. Kandungan vitamin $\mathrm{C}$ dan vitamin $\mathrm{E}$ ( $\alpha$-tokoferol) kecambah kacang hijau per $100 \mathrm{~g}$ kacang hijau tersebut masing-masing sebesar 1,88 mg dan 0,32 mg. Aktifitas enzim antioksidan superoksida dismutase (SOD) dan aktivitas penghambatan peroksidase kecambah kacang hijau juga mengalami peningkatan yaitu masing-masing menjadi 363 U SOD/g kecambah kacang hijau dan 26,2\% (14). Aktivitas antioksidan SOD pada konsentrasi $500 \mu \mathrm{g} /$ $\mathrm{mL}$ sebesar 53,28\% scavenging, aktivitas antoksidan dilihat dari penangkapan radikal DPPH pada konsentrasi $500 \mu \mathrm{g} /$ $\mathrm{mL}$ sebesar 56,94\% scavenging dan aktivitas antioksidan total (TAA) pada konsentrasi $500 \mu \mathrm{g} / \mathrm{mL}$ kacang hijau yaitu $1,19 \mathrm{mmol} / \mathrm{L}(15)$.

Dengan demikian, selain kecambah kacang hijau dikenal sebagai pangan lokal masyarakat Indonesia, kecambah kacang hijau juga mempunyai potensi 
untuk dikembangkan sebagai pangan fungsional yang diyakini bermanfaat untuk kesehatan khususnya bagi hiperlipidemia. Beberapa penelitian mengungkapkan bahwa vitamin E sebagai senyawa antioksidan berperan penting untuk menghambat meningkatnya produk peroksidasi lipid misalnya MDA. Penelitian tentang pengaruh konsumsi kecambah kacang hijau sebagai pangan lokal masyarakat yang diketahui memiliki nilai gizi dan komponen bioaktif antioksidan perlu dilakukan. Oleh karena itu, penelitian ini bertujuan untuk mengetahui pengaruh pemberian kecambah kacang hijau terhadap kadar MDA plasma dan MDA jaringan hati tikus Sprague Dawley yang diberi pakan lemak tinggi.

\section{BAHAN DAN METODE}

Penelitian ini merupakan penelitian eksperimental dengan desain penelitian post-test only with control group. Subjek penelitian adalah hewan coba tikus jantan galur Sprague Dawley, berat 147-222 g per ekor, usia dua bulan, diperoleh dari Fakultas Peternakan Institut Pertanian Bogor (IPB) Bogor. Jumlah subjek penelitian adalah 35 ekor kemudian dibagi menjadi 5 kelompok. Perhitungan jumlah subjek penelitian per kelompok berdasarkan pada perhitungan sampel minimum (15) sehingga diperoleh jumlah masing-masing kelompok adalah 7 ekor tikus. Penelitian dilaksanakan di Pusat Studi Pangan dan Gizi Universitas Gadjah Mada (PSPG UGM), pada bulan April-Juni 2015.

Bahan penelitian adalah kecambah kacang hijau segar (mentah) yang diperoleh dari proses perkecambahan biji kacang hijau selama 48 jam, lalu dihaluskan. Pakan tikus standar diformulasikan menurut standar AIN-93 dan pakan lemak tinggi dibuat dari pakan standar AIN-93M yang disuplementasikan dengan lemak sapi (tallow) (16). Vitamin E yang digunakan pada penelitian ini adalah vitamin E komersial. Kecambah kacang hijau yang sudah dihaluskan dan vitamin $\mathrm{E}$ pada hewan coba diberikan melalui sonde. Komposisi pakan standar dan pakan lemak tinggi dapat dilihat pada Tabel 1. Tikus diadaptasikan terlebih dahulu selama 3 hari dan diberikan pakan standar dan air minum ad libithum. Setelah masa adaptasi selesai, tikus dibagi ke dalam 5 kelompok (kelompok K1, K2, P1, P2 dan P3) dengan masing masing kelompok berjumlah 7 ekor.
Tabel 1. Komposisi pakan standar dan pakan lemak tinggi

\begin{tabular}{lcc}
\hline \multirow{2}{*}{ Komponen } & \multicolumn{2}{c}{ Komposisi (g/kg diet) } \\
\cline { 2 - 3 } & $\begin{array}{c}\text { Pakan standar } \\
\text { AIN-93M }\end{array}$ & $\begin{array}{c}\text { Pakan lemak } \\
\text { tinggi (PLT) }\end{array}$ \\
\hline Pati jagung & 620,692 & 440,66 \\
Kasein & 140 & 140 \\
Sukrosa & 100 & 100 \\
Minyak kedelai & 40 & 40 \\
Serat & 50 & 50 \\
Campuran mineral & 35 & 35 \\
Campuran vitamin & 10 & 10 \\
L-Sistin & 1,8 & 1,8 \\
Kholin bitartrat & 2,5 & 2,5 \\
Tert-butilhidroquinon & 0,008 & 0,04 \\
Lemak sapi & 0 & 180 \\
\hline Total & 1000 & 1000 \\
\hline
\end{tabular}

Tikus kelompok K1 merupakan kelompok tikus kontrol negatif yang diberi pakan standar dan aquades. Tikus kelompok K2 merupakan kelompok tikus kontrol positif yang diberi pakan lemak tinggi dan aquades tanpa diberi kecambah kacang hijau. Kelompok perlakuan P1 diberi pakan tinggi lemak (PLT) dan kecambah kacang hijau (KKH) 0,5 mL/g berat badan (BB); kelompok P2 diberi PLT dan KKH 1 mL/g BB; kelompok P3 diberi PLT dan vitamin E 23 IU. Setelah perlakuan selama 28 hari, tikus pada semua kelompok diambil sampel darahnya untuk diperiksa MDA plasma. Pengambilan darah dilakukan melalui belakang mata (retro-orbital flexus) tikus menggunakan hematokrit, ditempatkan dalam mikrotube yang sebelumnya sudah berisi EDTA. Darah kemudian disentrifus $4000 \mathrm{rpm}$ selama 15 menit dan diambil plasmanya untuk analisis kadar MDA plasma.

Selanjutnya, tikus dikorbankan dan diambil jaringan hatinya untuk diperiksa MDA jaringan hati. Cara pengambilan organ hati tikus yaitu tikus dibius dengan menggunakan kloroform lalu dikorbankan. Organ hati dicuci dengan larutan $\mathrm{NaCl}$ 0,9\% fisiologis. Organ hati sebanyak $1 \mathrm{~g}$ digerus lalu diseragamkan ukuran menggunakan homogenizer. Homogenat yang dihasilkan disentrifus $3000 \mathrm{rpm}$ selama 15 menit hingga diperoleh supernatan jernih. Supernatan yang dihasilkan selanjutnya digunakan untuk pengukuran kadar MDA jaringan hati. Analisis kadar MDA plasma dilakukan dengan metode thiobarbituric acid reactive substances 
(TBARS) (17) sedangkan analisis kadar MDA jaringan hati dilakukan menurut metode yang dilakukan oleh Singh et al. (2002) (18).

Pengolahan dan analisis data kadar MDA plasma dan MDA jaringan hati disajikan dalam bentuk rerata simpangan baku (rerata \pm SD). Setelah itu, data diuji normalitas dan varian menggunakan uji statistik non-parametrik Kruskal-Wallis dan Mann-Whitney test $(\mathrm{p}<0,05)$. Uji korelasi Spearman dilakukan ntuk mengetahui korelasi kadar MDA plasma dan MDA jaringan hati. Penelitian ini dilaksanakan setelah mendapatkan surat ethical clearance dari Komite Etik Fakultas Kedokteran Universitas Gadjah dengan surat nomor Ref:KE/FK/485/EC.

\section{HASIL}

\section{Kadar MDA plasma}

Hasil penelitian menunjukkan bahwa tikus kelompok K1 memiliki rerata kadar MDA plasma paling rendah sedangkan tikus kelompok K2 memiliki rerata kadar MDA plasma paling tinggi dibandingkan kelompok perlakuan lainnya. Kadar MDA plasma tikus kelompok P1 lebih rendah daripada kadar MDA plasma tikus kelompok K2, tetapi lebih tinggi daripada kadar MDA plasma pada kelompok P2 dan P3. Kadar MDA plasma tikus kelompok $\mathrm{P} 2$ lebih rendah daripada kadar MDA plasma tikus kelompok K2 dan P1, tetapi lebih tinggi daripada kelompok P3 (Tabel 2). Selanjutnya, dilakukan uji statistik nonparametrik Kruskall-Wallis karena varian data pada setiap kelompok tidak sama.

Tabel 2. Hasil analisis rerata dan standar deviasi kadar MDA plasma tikus

\begin{tabular}{cc}
\hline \multirow{2}{*}{ Kelompok } & MDA Plasma $(\mathbf{n m o l} / \mathbf{m L})$ \\
\cline { 2 - 2 } & $($ Mean \pm SD) \\
\hline K1 & $1,17 \pm 0,14$ \\
$\mathrm{~K}^{2}$ & $3,97 \pm 0,19$ \\
$\mathrm{P}^{3}$ & $2,94 \pm 0,09$ \\
$\mathrm{P}^{4}$ & $1,73 \pm 0,08$ \\
$\mathrm{P}^{5}$ & $1,53 \pm 0,07$ \\
\hline
\end{tabular}

${ }^{1}$ kelompok kontrol negatif yang diberi pakan standar dan aquades

${ }^{2}$ kelompok kontrol positif yang diberi PLT dan aquades tanpa KKH

${ }^{3}$ kelompok yang diberi PLT dan KKH dosis $0,5 \mathrm{~mL} / \mathrm{gBB}$

${ }^{4}$ kelompok yang diberi PLT dan KKH dosis $1 \mathrm{~mL} / \mathrm{gBB}$

${ }^{5}$ kelompok yang diberi PLT dan vitamin E dosis 23 IU

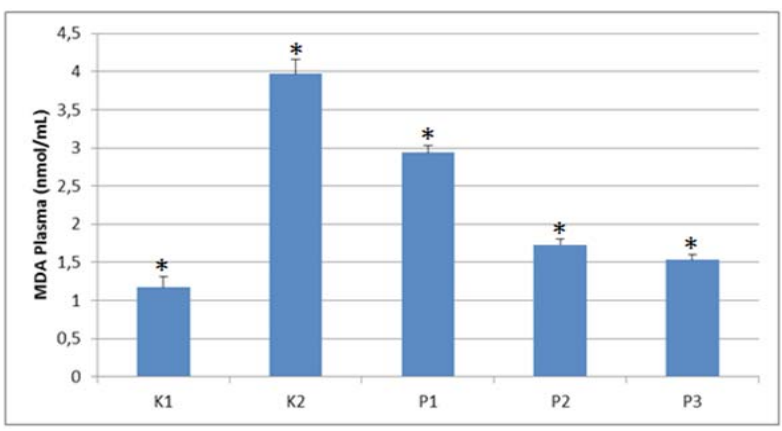

Gambar 1. Grafik perbandingan kadar MDA plasma tikus

*menunjukkan perbedaan rerata kadar MDA plasma yang signifikan antar kelompok $(\mathrm{p}<0,05)$ menggunakan uji Mann Whitney

Hasil uji Kruskall-Wallis menunjukkan bahwa terdapat perbedaan kadar MDA plasma paling tidak pada dua kelompok $(\mathrm{p}<0,05)$.

Hasil uji Mann Whitney pada Gambar 1 menunjukkan bahwa terdapat perbedaan kadar MDA plasma pada setiap kelompok $(\mathrm{p}<0,05)$. Kadar MDA plasma pada kelompok tikus yang diberi kecambah kacang hijau dosis $0,5 \mathrm{~mL} / \mathrm{g}$ BB (P1) dan $1 \mathrm{~mL} / \mathrm{g}$ BB (P2) lebih rendah dan signifikan daripada kelompok tikus yang tidak diberi kecambah kacang hijau (K2), tetapi lebih tinggi dan signifikan daripada kadar MDA plasma kelompok tikus yang diberi vitamin E 23 IU (P3).

\section{Kadar MDA jaringan hati}

Pada Tabel 3 menunjukkan bahwa kadar MDA jaringan hati tikus kelompok P1 lebih rendah daripada tikus kelompok $\mathrm{K} 2$, tetapi lebih tinggi daripada tikus kelompok P2 dan P3. Sementara rerata kadar MDA

Tabel 3. Hasil analisis rerata dan standar deviasi kadar MDA jaringan hati tikus

\begin{tabular}{cc}
\hline \multirow{2}{*}{ Kelompok } & MDA Jaringan Hati (nmol/g) \\
\cline { 2 - 2 } & (Mean \pm SD) \\
\hline K1 ${ }^{1}$ & $1,64 \pm 0,11$ \\
$\mathrm{~K}^{2}$ & $4,90 \pm 0,29$ \\
P1 $^{3}$ & $3,68 \pm 0,45$ \\
P2 $^{4}$ & $2,27 \pm 0,10$ \\
P3 $^{5}$ & $2,01 \pm 0,11$ \\
\hline
\end{tabular}

${ }^{1}$ kelompok kontrol negatif yang diberi pakan standar dan aquades

${ }^{2}$ kelompok kontrol positif yang diberi PLT dan aquades tanpa KKH

${ }^{3}$ kelompok yang diberi PLT dan KKH dosis $0,5 \mathrm{~mL} / \mathrm{gBB}$

${ }^{4}$ kelompok yang diberi PLT dan KKH dosis $1 \mathrm{~mL} / \mathrm{gBB}$

${ }^{5}$ kelompok yang diberi PLT dan vitamin E dosis 23 IU 
jaringan hati tikus kelompok P2 lebih rendah daripada kelompok K2 dan P1, tetapi lebih tinggi daripada tikus kelompok P3. Selanjutnya, untuk mengetahui apakah terdapat perbedaan bermakna pada kadar MDA jaringan hati pada kelima kelompok perlakuan, maka dilakukan uji statistik non-parametrik Kruskall-Wallis karena varian data pada setiap kelompok kadar MDA jaringan hati tidak sama.

Hasil uji Mann Whitney menunjukkan bahwa terdapat perbedaan kadar MDA jaringan hati pada setiap kelompok yaitu kelompok K1, K2, P1, P2 dan P3, dengan nilai $\mathrm{p}<0,05$ (Gambar 2). Kelompok tikus yang diberi kecambah kacang hijau (kelompok P1 dan P2) memiliki kadar MDA jaringan hati lebih rendah dan signifikan daripada kelompok tikus yang diberi pakan lemak tinggi dan tidak diberi kecambah kacang hijau (K2).

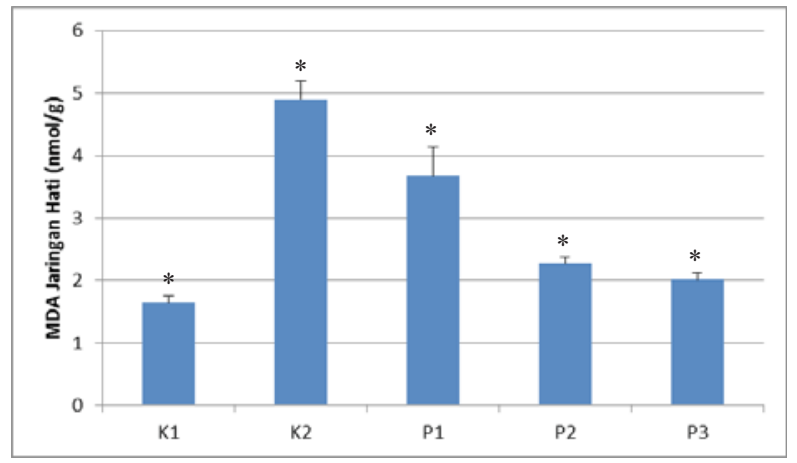

Gambar 2. Grafik perbandingan kadar MDA jaringan hati tikus

*menunjukkan perbedaan rerata kadar MDA plasma yang signifikan antar kelompok $(\mathrm{p}<0,05)$ menggunakan uji Mann Whitney

\section{Korelasi kadar MDA plasma dengan MDA jaringan} hati

Diagram korelasi kadar MDA plasma dengan MDA jaringan hati dapat dilihat pada Gambar 3. Korelasi kadar MDA plasma dan MDA jaringan hati tikus pada penelitian ini memiliki nilai $r=0,9844$ dan $p=0,0000$. Artinya bahwa korelasi kadar MDA plasma dengan MDA jaringan hati sangat kuat $(\mathrm{r}=0,9844)$, mempunyai arah korelasi positif, dan bermakna $(\mathrm{p}<0,05)$. Apabila kadar MDA plasma meningkat, maka akan diikuti dengan kenaikan kadar MDA jaringan hati pada setiap kelompok. Pada Gambar 3 juga diketahui bahwa terdapat hubungan linearitas yang sangat kuat. Rumus grafik linear y =
$1,1712 \mathrm{x}+0,2441$ mengartikan bahwa kenaikan kadar MDA plasma (x) sebesar 1 satuan (nmol/mL) akan diikuti dengan kenaikan kadar MDA jaringan hati (y) sebesar 1,4153 satuan $(\mathrm{nmol} / \mathrm{g})$.

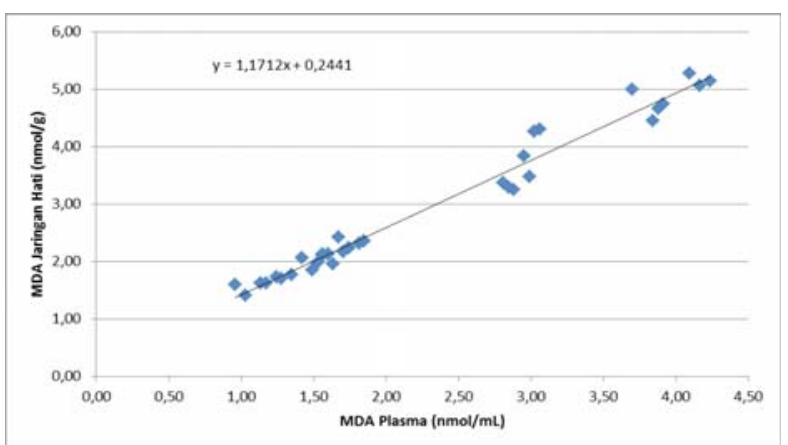

Gambar 3 . Diagram korelasi kadar MDA plasma dengan MDA jaringan hati

\section{BAHASAN}

Tingginya kadar MDA plasma pada tikus kelompok K2 merupakan indikator bahwa telah terjadi stres oksidatif karena dekomposisi hidroperoksida lipid di dalam tubuh. Pemberian pakan lemak tinggi pada tikus kelompok K2 selama 28 hari dapat menyebabkan senyawa radikal bebas dan antioksidan di dalam tubuh tidak seimbang (19). Asam lemak tak jenuh ganda yang terdapat pada pakan lemak tinggi sangat mudah teroksidasi oleh senyawa spesies oksigen reaktif (ROS) sehingga terjadi proses peroksidasi lipid. Proses peroksidasi lipid pada asam lemak tak jenuh dapat membentuk senyawa aldehid seperti MDA dan diena konjugasi (6). Tikus kelompok K2 yang diberi pakan lemak tinggi tanpa diberi kecambah kacang hijau mengalami stres oksidatif yang ditandai oleh kadar MDA plasma yang tinggi, asupan makan rendah sehingga berat badan dan berat lemak tikus paling rendah daripada tikus kelompok K1, P1, P2, dan P3 (20).

Kadar MDA plasma lebih rendah pada tikus kelompok P1 dan P2, menunjukkan bahwa pemberian kecambah kacang hijau mampu meningkatkan daya tahan tubuh tikus terhadap kerusakan oksidatif akibat pemberian pakan lemak tinggi. Kemampuan oksidatif berkaitan dengan kemampuan aktivitas antioksidan pada kecambah kacang hijau yaitu flavonoid, asam fenol dan asam organik (21). Vitamin E dan senyawa fenolik memiliki kemampuan antioksidan dengan mekanisme memberikan atom $\mathrm{H}$ pada rantai reaksi 
radikal (22). $\alpha$-tokoferol yang mengandung gugus $-\mathrm{CH}$ akan mendonorkan atom hidrogen $(\mathrm{H})$ pada ROS. Vitamin E pada fase lipid (membran) menangkap radikal peroksil pada proses peroksidasi lipid dan melindungi asam lemak tak jenuh ganda (PUFA-H). Vitamin E bereaksi dengan radikal peroksil asam lemak tak jenuh ganda (PUFA-OO*) di fosfolipid membran sel, kemudian membentuk vitamin $\mathrm{E}$ radikal sedikit reaktif (radikal tokoferoksil) yang memutus rantai propagasi dari reaksi rantai radikal (23).

Kelompok tikus yang diberi vitamin $\mathrm{E}$ dan pakan lemak tinggi (P3) memiliki kadar MDA plasma lebih rendah daripada kadar MDA plasma tikus kelompok yang diberi kecambah kacang hijau (P1 dan P2). Adanya zat anti gizi pada kecambah kacang hijau diduga mempengaruhi kadar MDA plasma tikus kelompok P1 dan P2. Selain kandungan asam fitat, faktor lain yang diduga mempengaruhi kadar MDA plasma tikus kelompok P1 dan P2 adalah menurunnya kandungan vitamin E kecambah kacang hijau karena proses pengolahan (kecambah kacang hijau dihaluskan). Tokoferol dan tokotrienol dapat rusak oleh proses oksidasi maupun mekanis. Oksigen dan proses oksidasi berlangsung sangat cepat apabila terkena cahaya, panas, alkali dan adanya logam seperti $\mathrm{Cu}_{2}^{+}$dan $\mathrm{Fe}_{3}^{+}$(24).

Pemberian pakan tinggi lemak menyebabkan tingginya kadar MDA jaringan hati tikus (25). Lebih lanjut dijelaskan bahwa pemberian tinggi lemak dapat meningkatkan stres oksidatif pada hati, sehingga aktivitas enzim antioksidan dan glutathion menurun. Tingginya kadar MDA jaringan hati pada kelompok K2 disebabkan pemberian pakan lemak tinggi. Pemberian pakan lemak tinggi menyebabkan ketidakseimbangan antara senyawa oksidatif dan komponen antioksidan endogen maupun antioksidan dari diet, menyebabkan kondisi stres oksidatif (26), sehingga aktivitas antioksidan di dalam tubuh menurun, dengan demikian terjadi kerusakan sel-sel hati yang dapat merubah fungsi hati sebagai penetralisir senyawa yang berbahaya. Organ hati berperan penting pada proses detoksifikasi sehingga perlu dilakukan pengukuran kadar MDA untuk mengetahui tingkat kerusakan oksidatif. Organ hati mempunyai kemampuan untuk melakukan desaturasi asam lemak sehingga menyebabkan ketersediaan asam lemak tidak jenuh sensitif terhadap serangan dari senyawasenyawa radikal bebas.
Kadar MDA jaringan hati yang lebih tinggi pada tikus kelompok K2 merupakan tanda adanya radikal bebas yang dihasilkan dari senyawa toksik, menyebabkan kerusakan sel karena reaksi peroksidasi lipid pada membran yang mengandung asam lemak tak jenuh ganda (10). Malondealdehid diketahui sebagai produk hasil peroksidasi lipid yang bersifat toksik (7). Peroksidasi lipid yang terjadi di dalam hati dapat mengakibatkan gangguan pada membran sel mikrosom hati sehingga fungsi membran sel mikrosom dapat dirusak. Aktivitas enzimatik di dalam retikulum endoplasma hati di antaranya enzim untuk biosintesis trigliserida, katabolisme asam lemak, katabolisme kolesterol, biosintesis kolesterol serta aktivitas glukosa 6-fosfatase (27). Apabila membran sel mikrosom hati dirusak oleh peroksidasi lipid maka aktivitas enzim-enzim tersebut dapat terganggu.

Pada kelompok tikus yang diberi kecambah kacang hijau dosis $0,5 \mathrm{~mL} / \mathrm{gBB}$ dan $1 \mathrm{~mL} / \mathrm{gBB}$ (kelompok P1 dan P2) menunjukkan bahwa pemberian kecambah kacang hijau mampu menghambat terbentuknya MDA pada jaringan hati sehingga kadar MDA jaringan hati menjadi lebih rendah. Pemberian ekstrak kecambah kacang hijau dan etanol pada tikus dapat menurunkan kadar MDA jaringan hati dan meningkatkan enzim antioksidan endogen SOD (28). Hal ini dikaitkan dengan kandungan total fenolik, vitamin C, tokoferol, aktivitas vitamin E kecambah kacang hijau sebagai senyawa bioaktif yang cukup tinggi (14).

Adanya korelasi yang kuat antara kadar MDA plasma dengan kadar MDA jaringan hati berhubungan dengan proses peroksidasi lipid yang terjadi pada proses metabolisme lipid. Peroksidasi lipid terjadi di membran plasma dikarenakan asam lemak tidak jenuh ganda memiliki ikatan rangkap dua atau lebih. Selain membran plasma, membran hati juga sensitif terhadap peroksidasi lipid, karena membran hati banyak mengandung asam lemak tak jenuh ganda, sehingga mudah sekali teroksidasi oleh radikal bebas. Proses oksidasi terjadi di membranmembran sel dan butir-butir lemak di dalam jaringan lemak dan pada sel-sel lainnya. Proses peroksidasi lipid oleh radikal bebas seperti radikal hidroperoksil $\left(\mathrm{H}_{2}\right)$, radikal superoksida $\left(\mathrm{O}_{2}\right)$ dan hidroksil radikal $(\mathrm{OH})$ dibentuk dalam sel sebagai senyawa intermediet dari transfer elektron di mitokondria sel hati sehingga lebih mudah menyerang jaringan ekstrahepatik (29). 
Reaksi peroksidasi lipid tersebut berlangsung secara terus menerus, menghasilkan lipid radikal bebas yang lain sehingga proses peroksidasi berlangsung lebih lanjut. Produk peroksidasi lipid yaitu MDA lebih banyak terdapat di jaringan dibandingkan di dalam darah (10). Kadar MDA jaringan hati lebih tinggi daripada MDA plasma setelah pemberian diet tinggi lemak (minyak kelapa dan butterfat ghee) walaupun tidak signifikan (30). Semakin tinggi kadar MDA plasma maka semakin besar pula kadar MDA jaringan hati tikus pada setiap kelompok perlakuan. Tikus yang diberi pakan lemak tinggi memiliki kadar MDA jaringan hati lebih tinggi daripada MDA plasma (25). Tikus obesitas akan meningkatkan peroksidasi lipid di hati, jantung dan jaringan ginjal, yang ditandai oleh peningkatan kadar MDA pada jaringan.

\section{SIMPULAN DAN SARAN}

Pemberian kecambah kacang hijau berpengaruh terhadap kadar MDA plasma dan MDA jaringan hati tikus yang diberi pakan lemak tinggi. Kadar MDA plasma dan jaringan hati tikus kelompok P1 dan P2 lebih rendah daripada kadar MDA plasma dan jaringan hati tikus kelompok K2, tetapi lebih tinggi daripada kadar MDA plasma dan jaringan hati tikus kelompok P3. Terdapat hubungan kategori sangat kuat antara kadar MDA plasma dengan MDA jaringan hati tikus yang diberi kecambah kacang hijau dan pakan lemak tinggi. Berdasarkan simpulan tersebut, maka perlu dilakukan penelitian mengenai identifikasi antioksidan endogen misalnya enzim SOD, Cat, GPX, dan vitamin E pada tikus yang diberi kecambah kacang hijau dan pakan tinggi lemak.

\section{Pernyataan konflik kepentingan}

Penulis menyatakan tidak ada konflik kepentingan dengan pihak-pihak yang terkait dalam penelitian ini.

\section{RUJUKAN}

1. World Health Organization. Global atlas on cardiovascular disease prevention and control. Geneva: World Health Organization; 2011.

2. Badan Penelitian dan Pengembangan Kesehatan Kementerian Kesehatan RI. Riset kesehatan dasar (Riskesdas 2013). Jakarta: Kemenkes RI; 2013.
3. Mahley RW, Bersot TP. Drug therapy for hypercholesterolemia and dyslipidemia. In: Brunton LL, Lazo JS, Parker KL, editors. Goodman and gilman's the pharmacological basis of therapeutics. 11th ed. Ch. 35. New York: McGraw-Hill; 2006.

4. Nelson RH. Hyperlipidemia as a risk factor for cardiovascular disease. Prim Care 2013;40(1):195-211.

5. Muchtadi D. Antioksidan dan kiat sehat di usia produktif. Bandung: Penerbit Alfabeta; 2013.

6. Yang RL, Shi YHS, Li W, Le GW. Increasing oxidative stress with progressive hyperlipidemia in human: relation between malondialdehyde and atherogenic index. J Clin Biochem Nutr 2008;43(3):154-8.

7. Yang TC, Chen YJ, Chang, SF, Chen, CH, Chang PY, Lu SC. Malondialdehyde mediates oxidized LDL-induced coronary toxicity through the Akt-FGF2 pathway via DNA methylation. J Biomed Sci 2014;21(1):11.

8. Cohen JH, Kristal AR, Stanford JL. Fruit and vegetable intakes and prostate cancer risk. J Natl Cancer Inst 2000;92(1):61-8.

9. Packer L, Weber SU. The role of vitamin E in the emerging field of nutraceuticals. In: Kramer K, Hope PP, Packer L, editors. Nutraceuticals in health and disease prevention. New York: Marcel Dekker; 2001.

10. Haggag MESY, Elsanhoty RM, Ramadan MF. Impact of dietary oils and fats on lipid peroxidation in liver and blood of albino rats. Asian Pac J Trop Biomed 2014;4(1):52-8.

11. Webb GP. Dietary supplements and functional foods. UK: Blackwell Publishing; 2006.

12. Murdiati A, Amaliah. Panduan penyiapan pangan sehat untuk semua. Jakarta: Penerbit Kencana Prenadamedia Group; 2010.

13. Anggrahini S. Pengaruh lama pengecambahan terhadap kandungan $\alpha$-tofoferol dan senyawa proksimat kecambah kacang hijau (Phaseolus radiatus L.). Agritech 2007;27(4):152-7.

14. Orozco RF, Frias J, Zielinski H, Piskula MK, Kozlowska H, Valverde CV. Kinetic study of the antioxidant compounds and antioxidant capacity during germination of Vigna cv. emmerald, Glycine max cv.jutro and Glycine max cv.merit. Food Chemistry 2008;111:622-30.

15. Dell RB, Holleran S, Ramakrishan R. Sample size determination. ILAR Journal 2002;43(4):207-13.

16. Reeves PG, Nielsen FH, Fahey Jr GC. AIN-93 purified diets for laboratory rodents : final report of the american institute of nutrition ad hoc witting commite on the reformation of the AIN-76A rodent diet. J Nutrition 1993;123(11):1939-51.

17. Wuryastuti H, Raharjo S, Warsito R. Peroxidation index: methods of analysis and diagnostic value. research report. Jakarta: Directorate Generale of Higher Education of Indonesia; 1996. 
18. Singh RP, Murthy KNC, Jayaprakasha GK. Studies on the antioxidant activity of pomegranate (Punica granatum) peel and seed extracts using in vitro models. J Agric Food Chem 2002;50:81-6.

19. Birben E, Sahiner UM, Sackesen C, Erzurum S, Kalayci O. Oxidative stress and antioxidant defense. World Allergy Organ J 2012;5(1):9-19.

20. Lestari D. Pengaruh pemberian kecambah kacang hijau terhadap berat lemak, jumlah sel lemak dan diameter sel lemak retroperitoneal tikus Sprague Dawley yang diberi diet tinggi lemak [Tesis]. Yogyakarta: Pascasarjana Universitas Gadjah Mada; 2015.

21. Tang D, Dong Y, Ren H, Li L, Congfen H. A review of phytochemistry, metabolite changes, and medicinal uses of the common food mung bean and its sprouts (Vigna radiata). Chem Cent J 2014;8(1):4.

22. Shahidi F, Naczk M. Food phenolics: sources, chemistry, effects, applications. United States: Techomic Publishing Company; 2004.

23. Botham KM, Mayes PA. Lipid yang penting secara fisiologis. In: Murar RK, Bender DA, Botham KM,
Kennelly PJ, Rodwell VW, Weil PA, editors. Biokimia Harper Edisi 29. Jakarta: EGC; 2014.

24. Andarwulan N, Koswara S. Kimia vitamin. Jakarta: Penerbit CV Rajawali; 1992.

25. Noeman SA, Hamooda HE, Baalash AA. Biochemical study of oxidative stress markers in the liver, kidney, and heart of high fat diet induced obesity in rats. Diabetol Metab Syndr 2011;3(1):17.

26. Omaye ST. Food and nutritional toxicology. New York: CRC Press LLC; 2004.

27. Gibson G, Skett. Pengantar metabolisme obat. Jakarta: UI Press; 1991.

28. Lee SJ, Lee JH, Lee. Effect of mung bean ethanol extract on pro-in ammtory cytokines in LPS stimulated macrophages. Food Sci Biotechnol 2011;20(2):519524.

29. Winarsih H. Antioksidan alami dan radikal bebas. Yogyakarta: Penerbit Kanisius; 2007.

30. Yao J, Zhi M, Chen M. Effect of silybin on highfat-induced fatty liver in rats. Braz J Med Biol Res 2011;44(7):652-659. 